\title{
REPOSISI DESA SEJUTA LONTAR BERDASARKAN ANALISIS SWOT
}

(Studi pada Desa Hendrosari Kecamatan Menganti, Kabupaten Gresik, Jawa Timur)

\author{
Achmad Daengs GS \\ Aridha Prassetya \\ email : bumigora@gmail.com \\ Fakultas Ekonomi Universitas 45 Surabaya
}

\begin{abstract}
ABSTRAK
Penelitian ini berfokus pada kegiatan ekonomi di pedesaan. Obyek penelitian adalah desa Hendrosari Kecamatan Menganti Kabupaten Gresik. Penelitian ini menarik karena adanya potensi tanaman Lontar seluas kurang lebih delapan puluh hektar, yang ternyata dapat merupakan inspirasi sumber penghidupan bagi penduduk setempat. Hasil dari tanaman Lontar yang utama diunggulkan adalah minuman yang berasal dari deresan bunga Lontar. Minuman ini dapat menjadi dua bentuk atau jenis, yakni legen dan toak. Legen, sebagian masyarakat masih mengidentikkannya dengan toak, padahal toak memiliki efek memabukkan bagi peminumnya, sementara legen tidak. Toak adalah legen yang telah mengalami fermentasi setelah didiamkan sekitar kurun waktu 3 jam. Legen dan toak,telah menjadi sumber penghidupan penduduk desa Hendrosari secara turun temurun dari generasi ke generasi. Oleh karenya, ketika krisis terjadi, kemampuan perempuan-perempuan di desa ini dalam hal memasak dan meramu bumbu membawa berkah tersendiri. Makin lama muncullah pengusaha warung-warung legen maupun toak, yang didalamnya dilengkapi dengan menu ayam panggang dan ragam ikan.
\end{abstract}

Kata Kunci ; positioning, repositioning, Lontar, ekonomi, swot.

\begin{abstract}
ABSTRACK
This research focuses on economic activities in rural areas. The object of this research is Hendrosari village. District of Menganti, Gresik Regency. This research is interesting because there was potential for palm plants of approximately eighty acres, which in fact, can be an inspiration of source of livelihood for local society. The most excellent results from palm plant is the drinks that come from tapped tree to extract sap of the palm flower. These drinks can be two forms or types, namely legen (unfermented palm wine) and toak (fermented palm wine). Some people still identically with toak, whereas toak has a heady effect for the drinkers, while legen is not. Toak is legen that has undergone fermentation after settling around within 3 hours. Legen and toak has been the source of livelihood of the Hendrosari villagers hereditary from generation to generation. Therefore, when the crisis was occurred, the ability of the women in this village in terms of cooking and mix seasoning are brought the blessings for themselves. As the time went on, entrepreneurs emergical the stalls of toak and legen, which is prepared with menu of grilled chicken and varieties of fish.
\end{abstract}

Keyword : positioning, repositioning, Lontar, ekonomic, swot. 


\section{PENDAHULUAN}

Dimanapun, krisis adalah sebuah persoalan yang perlu diwaspadai. Akibat krisis antara lain adalah kelaparan, kemiskinan, pengangguran dan kriminalitas, meskipun pada sebagian masyarakat, ada yang diuntungkan oleh kondisi krisis. Persoalan yang timbul sebagai dampak dari krisis dapat diatasi dengan cara menggiatkan aktivitas yang dapat menjamin kontinuitas kehidupan ekonomi masyarakat. Kontinuitas kehidupan ekonomi pada gilirannya akan meningkatkan daya beli dan kesejahteraan masyarakat yang bersangkutan.

Banyak ahli ekonomi sepakat bahwa sektor pertanian dianggap paling tahan terhadap guncangan. Indonesia adalah negara besar dengan ragam daerah menghasilkan ragam komoditas pertanian dan budaya. Sebetulnya, dari dua poin ini saja, yakni pertanian dan budaya, apabila ditangani dengan serius, akan dapat menggiatkan kehidupan ekonomi masyarakat. Dengan demikian, maka kemakmuran dan kesejahteraan masyarakat, dapat tercapai.

Persoalannya adalah bahwa tidak semua segmen masyarakat mampu mengenali potensi di sekitarnya. Seandainyapun mereka mampu mengenali potensinya, 'tidak semuanya memiliki kepekaan yang memadai' untuk mewujudkannya menjadi suatu kegiatan ekonomi yang dapat menghasilkan, sebagai sumber mata pencaharian.

Hendrosari, sebuah desa yang terletak sekitar 7 kilo meter dari perbatasan antara wilayah Surabaya Barat dan Gresik merupakan salah satu dari ratusan desa yang ada di Jawa Timur, yang berhasil menemukan sekaligus menyadari potensi desanya.
Lebih jauh lagi, desa ini mampu mewujudkan potensi desanya menjadi suatu kegiatan ekonomi yang menghasilkan. Dari luas desa yang 192 hektar, 75 hektar merupakan luasan area yang ditumbuhi pohon siwalan (Lontar). Dari pohon inilah secara turun temurun masyarakat desa ini menuai penghasilan untuk menghidupi keluarganya.

Yang menarik adalah ketika sebelum krisis 1997, out put dari pohon Lontar yang dapat dijual hanyalah minuman yang dihasilkan dari bunga Lontar (Legen dan Toak) dan buah Lontar. Tetapi kondisi krisis justru mampu menstimulasi masyarakat setempat mengemas sedemikian rupa out put dari tumbuhan Lontar tersebut.

Legen dan buah dilengkapi dengan menu komplemen khas desa, ayam dan ikan bakar. Bahkan luasan area lahan yang ditumbuhi rindang tumbuhan Lontar pun, ternyata juga merupakan daya pikat dan memiliki nilai jual tersendiri.

Sejak tahun 2001, kehidupan ekonomi masyarakat setempat mengalami peningkatan. Warung warung di area ini mulai bertambah jumlahnya. Menu yang wajib ada pada setiap warung adalah minuman legen. Sementara hasil survey awal, wawancara dengan para konsumen menyatakan bahwa rasa khas legen dan bumbu khas ayam bakar desa ini tidak ditemui di tempat lain.

Kini masyarakat desa ini, tak lagi harus susah susah mengayuh sepeda ke kota untuk menjual hasil kebunnya, karena masyarakat di luar sudah mulai banyak mengenal desa ini. Bahkan desa Hendrosari oleh masyarakat sudah diidentikkan dengan pohon siwalan (yang dimaksud adalah tumbuhan Lontar). Pohon siwalan dan Legen yang dihasilkan sudah merupakan trade mark desa Hendrosari. 
Beberapa fenomena yang menarik untuk diamati, terjadi di desa ini :

1. Hingga saat ini, ayam kampung dan ragam ikan yang merupakan bahan hidangan lauk sebagai komplemen dari minuman andalan yang dihasilkan dari tumbuhan Lontar, justru dipasok dari tempat lain, bukan dari desa setempat.

2. Menurunnya minat generasi muda untuk tetap membudidayakan tumbuhan pohon Lontar ini, mereka belum melihat adanya peluang yang ada di depan mata, namun justru kebanyakan lebih tertarik bekerja di pabrik atau industri pengolahan yang juga makin tumbuh subur di sekitar wilayah ini.

3. Tumbuhnya industri pengolahan dan permukiman baru disinyalir akan mempersempit area lahan tumbuhan pohon siwalan di desa ini.

4. Penyalahgunaan minuman ini oleh sebagian konsumen pendatang untuk mabuk-mabukan sebagai arak bukan Legen).

Fenomena ini sangat menarik untuk dikaji dan dianalisis dalam rangka menghasilkan pemikiran ke depan bagi sebuah desa yang sebenarnya memiliki nilai jual yang tinggi, namun terancam kontaminasi pertumbuhan modernitas.

\section{RUMUSAN MASALAH}

Bagaimana membangun sinergi yang kuat antara masyarakat petani Lontar dan masyarakat desa Hendrosari, Kecamatan Menganti, Kabupaten Gresik Jawa Timur dengan masyarakat Industri yang mulai tumbuh di sekitar wilayahnya, agar desa ini mendapat positioning yang tepat $\mathrm{di}$ benak pasarnya?

\section{TINJAUAN TEORI}

Teori yang dirujuk dalam penelitian ini adalah teori pemasaran khususnya produk, posisioning dan pemasaran daerah.

\section{Produk}

Produk adalah segala sesuatu yang ditawarkan kepada pasar, untuk memuaskan suatu keinginan atau kebutuhan, termasuk barang fisik, jasa, pengalaman, acara, orang, tempat, properti, organisasi, informasi dan ide (Kotler \& Keller, 2008).

Berdasarkan definisi tersebut, dikemukakan produk adalah segala sesuatu. Tempat, juga merupakan produk. Tempat dengan segala atribut yang meliputinya dapat ditawarkan kepada pasar (segmen tertentu) untuk memuaskan kebutuhan mereka. Dengan demikian, dalam konteks pengkajian ilmu pemasaran, desa Hendrosari dapat dianalogkan sebagai produk.

\section{Positioning}

Positioning adalah tindakan merancang penawaran dan citra perusahaan agar mendapatkan tempat yang khusus dalam pikiran pasar sasaran. Tujuannya adalah menempatkan merek dalam pikiran konsumen untuk memaksimalkan manfaat potensial bagi perusahaan (Kotler \& Keller, 2008)

Definisi tersebut menggagas positioning dalam konteks perusahaan, namun demikian dalam praktek, sesuai dengan definisi produk (yang juga menurut Kotler \& Keller, 2008), tempat dapat merupakan produk yang ditawarkan. Dalam relevansinya dengan penelitian ini, maka desa Hendrosari adalah produknya, sementara pemerintah pada tingkat kelurahan berperan sebagai produsen/perusahaannya.

Positioning berkenaan dengan benak/pikiran pasar. Lebih jauh lagi, Al Ries dan Trout (2001), mengemukakan bahwa positioning is not what you do to the product, but positioning is what you do to the mind of your prospect. 
Positioning adalah usaha untuk mendapatkan tempat dalam ruang benak/pikiran pelanggan/prospek. Dalam kaitannya dengan penelitian ini adalah usaha pemerintah setempat untuk meletakkan kesan yang mendalam tentang desa hendrosari, di dalam benak atau pikiran para pengunjung.

\section{Memasarkan suatu Daerah}

Dalam kondisi bangsa yang semakin mengalami pertumbuhan dan perkembangan, didukung dengan kenyataan pemberlakuan undang-undang otonomi daerah, maka daerah-daerah yang ada di Indonesia, secara ekonomis dihadapkan pada suatu tuntutan kemandirian. Inilah yang kemudian memicu operasionalisasi UndangUndang yang salah kaprah, sehingga yang muncul adalah ego masing-masing daerah, berpikir dan bertindak tidak tepat, guna tujuan meningkatkan PAD (Pendapatan Asli Daerah). Cara yang benar menyikapi pemberlakuan UndangUndang Otonomi Daerah adalah melalui persaingan yang fair antar daerah. Persaingan yang fair seyogyanya ditumpu oleh pengetahuan yang benar tentang ilmu pemasaran.

Pada prinsipnya negara, daerah, kota, maupun desa, dapat dianalogkan sebagai suatu produk. Sebuah produk akan laku terjual dan dapat memperoleh keuntungan, hanya apabila ia memiliki nilai jual. Dengan demikian negara, daerah, kota dan desa juga memiliki nilai. Nilai ini dapat dijual. Inilah yang dinamakan dengan value. Dalam tataran sebuah negara, daerah, kota maupun desa, ada yang namanya target market. Menurut Kartajaya (2005), target market suatu negara, ada empat, yaitu :

a. Visitor (pengunjung), baik business maupun non business visitor.

Negara, daerah, kota dan desa harus berusaha dapat menarik pengunjung untuk datang, baik pengunjung yang melakukan aktivitas bisnis maupun pengunjung non bisnis, yang hanya sekedar berkunjung untuk berwisata.

\section{b. Resident}

Sebuah negara, daerah, kota maupun desa harus dapat mempertahankan penduduknya untuk tidak tertarik meninggalkan negara, daerah, kota, maupun desanya. Faktor mengapa terjadi apa yang dinamakan braindrain adalah dikarenakan negara, daerah, kota maupun desa tersebut tidak menarik untuk dijadikan tempat tinggal, maupun tempat aktivitas bisnis yang menguntungkan.

\section{c. Business Industry}

Negara, daerah, kota maupun desa harus dapat menarik perhatian industri sehingga industri ini bersedia menginvestasikan assetnya di sana. Dengan demikia akan terjadi hubungan yang sinergis antara keduanya. Faktor yang membuat industri tidak tertarik adalah karena negara, kota, daerah ataupun desa tidak menarik secara bisnis.

\section{d. Export Market}

Negara, daerah, kota dan desa, agar memiliki suatu nilai, maka harus dapat menciptakan suatu tawaran yang dapat menarik export market untuk datang dan atau bersedia mengadakan suatu transaksi yang menguntungkan.

\section{METODE PENELITIAN}

Lokasi penelitian dilaksanakan di Kabupaten Gresik, penelitian ini bersifat kualitatif yang berupaya mendeskripsikan suatu gejala kemasyarakatan. Pengambilan data primer dilakukan melalui pengamatan dan wawancara mendalam dengan sejumlah responden, sedangkan data sekunder diperoleh melalui studi 
dokumen, studi kepustakaan dan jurnal ilmiah.

\section{PEMBAHASAN}

\section{Kegiatan Ekonomi Desa Hendrosari}

Dalam relevansinya dengan sumber daya alam yang ada, maka Lontar merupakan satu-satunya potensi yang utama di desa Hendrosari. Dari tanaman Lontar penduduk desa ini dapat menghidupi keluarganya secara turuntemurun. Dengan kata lain Lontar merupakan penggerak utama (primemover), kegiatan ekonomi di desa ini. Mereka bergerak dari Warung Toak, yang kemudian berkembang menjadi restoran ayam panggang, meskipun dalam restoran itupun tetap dihidangkan minuman toak.

Dampak dari peningkatan kegiatan ekonomi adalah kemajuan dalam pemikiran akan pentingnya pendidikan. Sekarang ini banyak sarjana yang dihasilkan dari desa ini. Bahkan staf BPD (Badan Permusyawaratan Desa), meng-klaim bahwa jumlah sarjana asal desa ini adalah yang terbanyak jumlahnya dibanding sarjana yang dihasilkan oleh desa lain di wilayah yang sama, yakni Kecamatan Menganti Kabupaten Gresik. Sedih memang, bahwa sebuah Masjid yang cukup megah juga dibangun dengan swadaya dari penduduk desa setempat, yang notabene adalah bersumber dari hasil menjual minuman dari tumbuhan Lontar ini.

\section{Kendala Kegiatan Ekonomi dan Solusinya \\ Kegiatan ekonomi yang dikaji} dalam penelitian ini hanyalah pada lingkup kegiatan ekonomi warungwarung yang ada di desa Hendrosari, baik warung yang menyediakan minuman Toak atau Legen. Dalam prakteknya ada 2 kendala yang akan dikaji, yakni kendala ekonomis dan kendala sosial. a. Kendala ekonomis, yang dimaksud adalah adanya kasus atau fenomena keterbatasan dalam pemenuhan bahan untuk pelaksanaan kegiatan. Dalam hal warung-warung yang ada, ayam dan ragam ikan ternyata diperoleh dari desa atau daerah lain.

b. Kendala sosial adalah kendala dalam masyarakat terkait dengan keberadaan warung-warung yang semakin bertambah. Warung-warung yang ada, khususnya yang masih menyediakan Toak sebagai menu minuman inti dapat menstimulasi tindakan negatif karena minuman ini mempunyai efek memabukkan, yang pada gilirannya dapat memicu kriminalitas.

\section{SWOT Desa Hendrosari}

Variabel-variabel yang ditinjau guna mendeskripsikan SWOT desa Hendrosari antara lain adalah :

1) Penyerapan tenaga kerja (oleh restoran/warung)

2) Lokasi

3) Kontribusi pendapatan

4) Kualitas pengusaha legen

5) Kualitas SDM

6) Tingkat pengangguran

7) Kontribusi sektor pertanian

8) Kontribusi sektor lain

9) Restoran ayam panggang

10) Warung legen

11) Persepsi masyarakat

12) Pendapat para tokoh masyarakat

13) Pemasok ayam

14) Pemasok ikan

15) Pemasok legen

16) Permintaan pasar

17) permodalan

18) Dukungan kebijakan daerah

19) Dukungan kebijakan kecamatan

20) Dukungan kebijakan desa

21) Daya saing

22) Daya beli

23) Status hukum pohon siwalan 
Pengamatan terhadap variabelvariabel tersebut, menghasilkan informasi tentang SWOT desa Hendrosari. Secara rinci dapat dijelaskan sebagai berikut.

\section{Strengths (Kekuatan) Desa}

Kekuatan yang dimiliki desa Hendrosari terletak pada 6 variabel antara lain variabel lokasi, kontribusi pendapatan, restoran atau warung ayam panggang, persepsi masyarakat tentang legen, pendapat tokoh masyarakat dan pemasok legen.

\section{Lokasi}

Desa Hendrosari hanya ada satu pintu masuk yang memudahkan pengawasan terhadap orang luar atau tamu yang masuk, dengan demikian diharapkan hal ini akan meminimisasi kemungkinan kejahatan yang terjadi. Tempatnya yang masih asri (dengan hamparan tumuhan Lontar) dan asli memungkinkan desa ini mempunyai potensi kuat unttuk dijadikan desa pariwisata . berita informal yang pernah diterima personal pemerintahan desa dari Bappekab (Badan Perencanaan dan Pembangunan Kabupaten) Gresik adalah bahwa dalam jangka panjang, desa Hendrosari layak diunggulkan sebagai Desa Wisata.

\section{Kontribusi Pendapatan}

Pendapatan bersih pemilik restoran atau warung yang dikelola dengan baik mencapai Rp 5 juta sampai di atas Rp 10 juta per bulan. Pendapatan penderes legen dapat mencapai antara Rp 100.000,- hingga mencapai Rp 200.000,per hari, jika permintaan tinggi pada hari-hari libur atau ada pesta. Pendapatan pemilik warung-warung legen cukup untuk memenuhi kebutuhan keluarga.

Bahkan, berdasarkan hasil riset di lapangan, ada dua warung (Ibu Suminah dan Ibu Wati), yang pada hari-hari libur dapat mencapai omzet penjualan yang tergolong sangat tinggi dan fantastis untuk ukuran penghasilan penduduk desa. Pada hari libur, ayam yang disembelih pernah mencapai jumlah seratus hingga dua ratus ekor. Jika seekor ayam panggang dihargai $\mathrm{Rp}$ 40.000,- maka omzet mereka untuk penjualan ayam panggang saja bisa mencapai Rp 8.000.000,- (delapan juta rupiah) tiap bulan. Belum termasuk yang dihasilkan dari pesanan lain seperti ragam ikan bakar, belut dan bandeng.

Sementara itu harga legen asli dari petani Lontar dijual kepada pemilik warung dengan harga Rp 5000,- per liter dan oleh pemilik warung, dijual kepada konsumen dengan harga Rp 10.000,- per liter.

\section{Restoran/Warung Ayam Panggang}

Empat buah restoran/warung ayam panggang merupakan kekuatan daya tarik tersendiri bagi desa Hendrosari. Restoran ini merupakan kekuatan karena menu yang ditawarkan tidak ditawarkan di tempat lain. Masing-masing restoran memiliki keunggulan bumbu yang khas. Bahkan Legen yang dihidangkannya pun memiliki cita rasa yang khas.

Disamping warung atau rumah makan, ada puluhan warung-warung kecil yang hanya menjual makanan ringan dengan menu utama yang diandalkan adalah minuman Legen atau Toak.

\section{Persepsi Masyarakat Tentang Legen}

Sebagian besar penduduk asli berpendapat bahwa Legen dan Toak sama-sama dapat memabukkan. Tetapi pada kenyataannya tidaklah demikian. Legen yang belum mengalami fermentasi tidak memiliki daya memabukkan, sedangkan Toak, yakni legen yang mengalami fermentasi dapat 
memiliki daya memabukkan bagi peminumnya. Inilah yang memberikan inspirasi bagi sebuah warung yang bernama Berkah Illahi untuk meluruskan pendapat masyarakat tersebut. Warung Berkah Illahi akhirnya telah berhasil menghapus keragu-raguan dalam masyarakat tentang hal ini. Akhir-akhir ini diketahui bahwa Legen dapat membantu meluruhkan batu ginjal. Hal ini telah banyak yang membuktikan, meskipun secara klinis belum diuji (justru inilah yang diharapkan dapat menstimulasi peneliti bidang lain yang memungkinkan untuk melakukan uji klinis kandungan yang ada dalam minuman khas tradisionil ini).

Usaha warung rumah makan Berkah Illahi untuk merubah mind set dari masyarakat dimanifestasikan dalam bentuk surat perjanjian antara pemasok legen, yang dalam hal ini adalah petani Lontar dengan pemilik rumah makan. Sebagian besar masyarakat pengunjung maupun masyarakat umum yang sebelumnya meragukan kualitas dan efek dari minuman legen, menjadi teryakinkan setelah membaca perjanjian yang dibuat tersebut. Secara prinsip isi perjanjian menyatakan bahwa kualitas legen yang dihidangkan adalah asli, terjaga kualitasnya dan tidak memiliki efek memabukkan. Dengan demikian pengunjung yang mayoritas beragama Islam menjadi tak ragu-ragu mengkonsumsi minuman ini. Sekarang ini segmen pasar warung ini menjadi semakin luas.

\section{Pendapat tokoh masyarakat tentang legen}

Para tokoh masyarakat pun ternyata mempunyai pendapat bahwa bahwa minuman Toak dapat mempunyai efek memabukan. Oleh karena itu diadakan pengawasan pada warung-warung legen agar tidak menjadi tempat mabuk- mabukan (berlaku jam malam, warung dan restoran harus tutup jam 9 malam).

$$
\text { Warung legen diijinkan }
$$

keberadaannya karena dapat meningkatkan pendapatan masyarakat dan karena yang membeli kebanyakan bukan warga desa Hendrosari.

\section{Pemasok legen}

Hingga saat ini, pemasok kebutuhan Legen berasal dari desa Hendrosari sendiri. Hal ini merupakan kekuatan. Dalam kurun waktu maksimal 3 jam, legen akan mengalami fermentasi dan berubah menjadi Loak, yang dapat mempunyai efek memabukkan. Dengan dihasilkan dari dalam desa sendiri, keaslian dan kebersihannya dapat terjaga. Pembeli dapat memilih sendiri waktu meminumnya, meskipun hanya ada 2 pilihan yaitu pagi dan sore, bahkan dimungkinkan untuk datang sendiri ke pohonnya, tinggal menunggu tukang panjat atau petani Lontar menurunkan dari atas pohon.

\section{Weaknesses (Kelemahan)}

Kelemahan desa Hendrosari terletak pada 5 variabel antara lain variabel dukungan kebijakan daerah, dukungan kebijakan kecamatan, kontribusi sektor pertanian, kualitas pengusaha warung legen, penyerapan tenaga kerja.

\section{Dukungan Kebijakan Daerah}

Variabel ini merupakan kelemahan mengingat tidak ada kebijakan khusus dari kebupaten Gresik atas Hendrosari, selain pernyataan dalam profile Kabupaten Gresik 2006-2010 bahwa akan meningkatkan perekonomian berbasis kerakyatan dan usaha kecil. Namun demikian, ada berita dari Kantor Bappekab bahwa Hendrosari akan menjadi lokasi wisata.

\section{Dukungan Kebijakan Kecamatan}

Dukungan kecamatan pun masih dianggap lemah mengingat tidak ada 
kebijakan khusus tentang pengembangan desa Hendrosari.

\section{Kontribusi Sektor Pertanian}

Sebagian masyarakat desa

Hendrosari adalah petani (sebanyak 312 orang), yang selain hasil pertanian juga mendapat penghasilan dari tumbuhan Lontar yang terdapat di pematang sawah mereka. Sebagian besar lahan mereka di bawah 0,5 ha, yang ditanami padi ketika musim hujan. Hendrosari tak memiliki sumber air yang bagus sehingga sawah yang ada di sini merupakan sawah tadah hujan. Selebihnya mereka lebih memilih menjadi pegawai atau buruh pabrik, yang semakin lama juga semakin banyak jumlahnya didirikan di sekitar desa ini.

\section{Kualitas Pengusaha Warung Legen}

Kemampuan manajerial bisnis pengusaha restoran sangat sederhana, sebagaimana warung rakyat, kecuali pemilik restoran Berkah Ilahi yang secara tidak sadar sebagaian besar pengelolaannya, mengacu konsep marketing modern.

\section{Penyerapan Tenaga Kerja}

Restoran ayam panggang di desa Hendrosari sangat sedikit menyerap tenaga kerja. Kebanyakan tenaga kerja diambil dari saudara atau kerabat dari pemilik restoran sendiri.

\section{Opportunities (Peluang)}

Peluang desa Hendrosari terletak pada 7 variabel antara lain tingkat pengangguran, pemasok ayam, pemasok ikan, permintaan pasar, permodalan, daya saing dan daya beli.

\section{Tingkat Pengangguran}

Tingkat pengangguran meningkat karena banyaknya pabrik-pabrik di sekitar lokasi yang mengurangi jumlah karyawan dikarenakan menurunnya produksi. Realisasi impian menjadi desa wisata dapat melihat hal ini sebagai peluang, melalui pembinaan dan pemberian kesempatan untuk memberdayakan potensi yang ada.

\section{Pemasok Ayam}

Selama ini pemasok ayam di restoran ayam bakar berasal dari Lamongan, Kediri, Mojokerto dan Ngampon (Menganti). Mereka merupakan pemasok tetap dan siap kirim berapapun pesanan restoran-restoran tersebut. Inilah yang dikatakan sebagai peluang bisnis yang mestinya dimanfaatkan oleh penduduk setempat.

\section{Pemasok Ikan}

Pemasok kebutuhan ikan di restoran ayam panggang maupun di warung legen adalah dari pedagang di pasar Benowo, yang terletak di perbatasan wilaya kota Surabaya dan Kabupaten Gresik. Ini juga merupakan peluang penduduk setempat untuk dapat memanfaatkannya.

\section{Permintaan Pasar}

Restoran ayam panggang dalam sehari bisa terjual 10 ayam dalam kondisi sepi, dan bila ramai pada harihari libur atau ketika ada pesta bisa mencapai 80 hingga ratusan ekor ayam. Yang dimaksud hari-hari libur adalah hari sabtu, minggu, hari libur nasional. Bahkan warung-warung yang bias digunakan konsumen untuk mengadakan pertemuan atau rapat-rapat informal. Ada salah satu warung yakni Berkah Illahi, yang bahkan menyediakan ruang khusus untuk pesta atau pertemuan bagi konsumen yang menghendaki. Ruangan ini bahkan telah dilengkapi dengan AC.

\section{Permodalan}

Bank BPD, BNI, BRI siap memberikan pinjaman dalam usaha restoran ayam panggang ini. Bahkan hal ini juga merupakan peluang yang dapat 
dimanfaatkan oleh lembaga desa yang bernama koperasi.

\section{Daya Saing}

Kemampuan pemilik warung meramu bumbu merupakan keunggulan sekaligus peluang. Ayam panggang desa Hendrosari khas dan enak yaitu pedas dan bumbu tradisional (desa). Selain itu ayam yang dipasok adalah ayam kampung. Dengan demikian ini merupakan daya saing.

\section{Daya Beli}

Berdasarkan hasil wawancara dengan pembeli dan warga setempat, harga Legen sangat terjangkau. Sedangkan harga ayam panggang relatif mahal bila dibandingkan dengan pendapatan penduduk yang berkisar antara Rp 450.000,- s/d Rp 750.000,-. Tetapi untuk masyarakat di luar Hendrosari (Surabaya dan Gresik kota), harganya relatif bersaing.

\section{Threat (Ancaman/Tantangan)}

Tantangan desa Hendrosari terletak pada 4 variabel antara lain kualitas SDM, kontribusi sektor lain, dukungan kebijakan desa, status hukum tumbuhan Lontar

\section{Kualitas SDM}

Tingkat pendidikan warga desa mulai meningkat (Sekolah Menengah Atas). Di satu sisi hal ini baik karena tingkat kesadaran masyarakat atas kualitas hidup dan kebersihan meningkat, tetapi disisi lain mereka tidak berminat terhadap pekerjaan yang terkait dengan tumbuhan Lontar yang ada.

\section{Kontribusi Sektor Lain}

Sebanyak 545 orang penghasilannya berasal dari luar sektor pertanian. Penghasilan mereka antara Rp 450.000,s/d Rp 750.000,- per bulan. Pendapatan yang sudah jelas per bulan dari pabrik atau perusahaan akan lebih menarik bagi penduduk desa dari pada pendapatan dari hasil menek (manjat Lontar). Bekerja di perusahaan lebih mengesankan dan meningkatkan status, bagi mereka.

\section{Dukungan Kebijakan Desa}

Meskipun Kepala desa sepenuhnya setuju dengan pengembangan warungwarung legen dan restoran ayam panggangnya, namun dalam prakteknya pemerintah desa tidak punya daya ketika lahan-lahan ini mulai dijual penduduk kepada para investor pemukiman baru. Desa mendukung mempertahankan lahan/tanaman siwalan sebagai komoditi dan ciri khas desa Hendrosari, namun di sisi lain melarang pengembangan usaha peternakan ayam karena polusi bau dan kotor. Pemanfaatan bendungan desa untuk budidaya ikan memang dikelola karang taruna, tetapi terkesan tidak serius, meskipun pengembangan kolam pancing ini merupakan hasil dana kerjasama dengan BPD.

\section{Status Hukum Tumbuhan Lontar}

Ini merupakan tantangan atau hambatan yang jelas jangka panjang. Tumbuhan Lontar yang ada sekarang adalah tumbuh di pematang sawah atau tegalan dan sekarang lahan yang ada tersebut telah banyak yang laku dijual, sehingga bukan lagi menjadi milik petani dimana tumbuhan Lontar tersebut tumbuh.

Pembelian ini tidak jelas jangka waktunya, sehingga menimbulkan banyak masalah dengan pemilik tanah/lahan yang ditumbuhi pohon siwalan. Sering terjadi kontroversi bahwa yang dibeli tersebut adalah lahan bukan tumbuhan Lontar-nya, sehingga 
petani sering bersikeras bahwa yang jadi milik orang lain adalah lahannya saja sedang tumbuhan Lontarnya tetap akan menjadi milik petani dan dapat dipanjat semau mereka.

\section{Membangun Sinergi Antara Petani Lontar, Pengusaha dan Industri}

Untuk melayani permintaan ayam panggang dan ragam lauk yang lain, sangat disayangkan bahwasannya kapasitas yang dihasilkan dari desa sendiri sangat tidak mencukupi. Oleh karenanya, pemilik warung cenderung mengatasi persoalan kebutuhan bahan ini, dengan berbelanja di pasar, atau mencari pemasok dari desa lain, tidak jarang pemilik warung bahkan sampai menelusur ke daerah lain yang cukup jauh hingga ke Lamongan. Hal inilah yang menginspirasi penulis untuk menciptakan suatu kerjasama yang sinergis antara petani Lontar, pemilik warung dan peternak yang ada di desa.

Konsep yang diusulkan adalah, mendidik dan memberdayakan penduduk desa untuk mengadakan suatu peternakan ayam dan budi daya ikan, guna mendukung kebutuhan pemilik warung agar tidak perlu lagi susah-susah memenuhi dari desa atau daerah lain. Tentu saja campur tangan dan peran pemerintah desa dan Dinas Pertanian juga sangat diperlukan guna pembinaan di bidang peternakan.

Sementara itu ada banyak pabrik dan perusahaan didirikan di sekitar desa Hendrosari. Yang dapat dilakukan adalah memasok hidangan makan siang atau menerima Jasa Catering dari pabrik atau perusahaan sekitar desa yang memiliki jumlah karyawan yang bahkan mencapai ribuan. Catatan data penelitian di lapangan menunjukkan adanya sebuah pabrik yang menghasilkan limbah yang berdampak kepada suburnya area pertanian di desa ini. Ini juga merupakan hubungan sinergis yang menarik.

Dalam jangka pendek, konsep membangun hubungan yang sinergis ini belum dapat dilaksanakan. Hasil penelitian di lapangan menunjukkan bahwa, ketika responden yang terdiri dari warga desa Hendrosari, ditanya tentang pendapatnya terhadap pembangunan peternakan ayam, dari 30 orang jumlah responden yang diteliti, 22 orang ( $73 \%$ ), menolak menyatakan tidak setuju, 3 orang (10\%) menyatakan kurang setuju, 3 orang (10\%) menyatakan setuju dan hanya 2 orang (7\%) yang menyatakan sangat setuju. Alasan penolakan atau ketidaksetujuan adalah bahwa peternakan ayam menyebabkan polusi bau dan limbah (kotoran) ayam memberi kesan kotor. Sebenarnya pernah ada pendatang yang usaha mendirikan peternakan ayam, dan warga sudah siap demo dikarenakan bau dan kotor lingkungan sekitar. Tetapi demo itu tidak sempat dilakukan karena usaha ternak ayam itu bangkrut sebelum sempat berkembang.

Bagaimanapun, masih ada potensi untuk diadakan atau direalisasi kerjasama sinergistik tersebut, mengingat ketika ditanya tentang minat atau ketertarikan, $47 \%$ menyatakan tertarik dan berminat. Alasan utama mengapa responden menjadi tertarik adalah, karena hal ini merupakan peluang bisnis. Tetapi kekurangan modal dan minimnya pengetahuan tentang beternak ayam dan budidaya ikan menyebabkan mereka kurang berani mencoba usaha ini. Di sinilah pentingnya Koperasi Desa dan Dinas 
Peternakan ikut terlibat dan berperan serta.

Jika kerjasama bersifat sinergis antara petani Lontar, wirausahawan (yang dalam hal ini adalah pemilik warung), pemerintah desa, koperasi desa dan dinas Peternakan dilakukan, maka desa Hendrosari akan dapat semakin meningkatkan kegiatan ekonomi di desa.

\section{KELEMBAGAAN}

Berdasarkan pembahasan sebelumnya, maka lembaga-lembaga yang dibutuhkan perannya untuk menjaga stabilitas dan guna peningkatan kegiatan ekonomi di desa Hendrosari adalah :

1. Dinas Pertanian

2. Koperasi Desa

3. Perbankan

4. Perlindungan Masyarakat.

Sebelum membahas lebih jauh, ada satu persoalan yang perlu dijawab. Persoalan tersebut adalah mengapa diperlukan suatu kerjasama kelembagaan ?. Kerjasama kelembagaan dibutuhkan karena ada beberapa hal yang meskipun secara sepintas nampak bersifat kasuistik, akan tetapi sangat mempengaruhi perkembangan kegiatan ekonomi yang sedang berlangsung dan citra desa Hendosari ke depan.

Dikaitkan dengan keberadaan tanaman Lontar yang pada gilirannya, jika tidak dikendalikan pemanfaatannya, maka perlu suatu peran serta keamanan yang dilembagakan. Hal ini dikarenakan pemanfaatan secara salah terhadap hasil tanaman Lontar, dapat menstimulasi tindakan negatif atau bahkan tindak kejahatan.

\section{Tentang Keterbatasan Kapasitas Suplai Ayam dan Ikan}

Selama ini kebutuhan pemilik resto atau warung akan ayam dan ikan dipenuhi dari luar. Berdasarkan wawancara dengan penduduk asli, lebih dari $40 \%$ responden yang diteliti menyatakan berminat untuk budi daya ikan. Ini adalah indikasi yang baik. Namun, seperti telah dikemukakan bahwa permodalan dan pengetahuan merupakan kendala bagi mereka. Hasil riset terhadap perikanan dan peternakan yang ada menyatakan tidak ada peternakan khusus di desa Hendrosari, hanya ternak ayam perorangan yang diperuntukan bagi kepentingan sendiri. Meskipun ada tambak dengan lokasi di Bendungan dan tambak milik pribadi dengan hasil ikan bandeng, bader, mujair, wader, udang, hasil tambak lebih cenderung dijual langsung ke agen (juragan) setiap panen. Hasil ini tidak bisa diharapkan mensuplai restoran di sekitar Hendrosari karena panennya tidak kontinu dan sekali panen hasilnya besar. Disinilah pentingnya peran pemerintah desa untuk membantu dan mengupayakan merealisasi kerjasama yang saling menguntungkan antara lembaga keuangan, yang dalam hal ini adalah lembaga perbankan yang memiliki keberpihakan kepada rakyat kecil, koperasi desa dan dinas Pertanian sebagai penyuluh pengetahuan budi daya ikan.

\section{Tentang Penodaan Citra Desa}

Dikaitkan dengan keberadaan tanaman Lontar yang pada gilirannya, jika tidak dikendalikan pemanfaatannya, maka perlu suatu peran serta keamanan yang dilembagakan. Hal ini dikarenakan pemanfaatan secara salah terhadap hasil 
tanaman Lontar, dapat menstimulasi tindakan negatif atau bahkan tindak kejahatan.

Namun demikian, sejalan dengan meningkatnya tingkat pengetahuan dan pendidikan penduduk setempat, maka muncullah usaha-usaha untuk melakukan Pencitraan kembali atas desa Hendrosari. Jika selama ini Toak sangat identik dengan kesan negatif (memabukkan), maka muncul suatu gagasan untuk memanfaatkan Legen sebagai minuman alternatif yang lebih memiliki nilai kesan positif. Karena keasliannya, legen memiliki cita rasa yang khas pula. Bahkan yang lebih menarik lagi, telah banyak kesaksian, legen dapat dijadikan sebagai obat penyakit batu ginjal.

Meskipun desa Hendrosari sekarang ini sudah terkenal dengan Legen dan Ayam Panggang nya, namun Toak masih banyak dikonsumsi oleh mereka yang datang dari luar. Pada hari libur, jika kita masuk lebih dalam ke kampungkampung, maupun ke area kebun Lontar, masih banyak dijumpai para pemabuk yang datang dari luar Hendrosari untuk menikmati Toak sambil memutar keraskeras lagu dang dut. Ini sangat tidak sedap dipandang mata, namun kebijakan dan pembinaan dilakukan secara pelanpelan oleh pemerintah desa. Bahkan ada sesuatu pemandangan yang ironis, ada salah satu Mushollah, yang dibangun persis bersebelahan dengan warung Toak penduduk.

Indikasi lain adanya penodaan citra desa adalah kondisi berikut: ketika masuk Gerbang Desa Hendrosari, pendatang akan dihadapkan pada peringatan yang berupa tulisan Bandar dilarang masuk!. Bandar adalah sebutan bagi perempuan-perempuan yang pekerjaannya menemani pemabuk untuk minum Toak. Bukan hanya itu, pengemis usia muda, pengamen atau sales pun dilarang. Hal ini tak lain adalah untuk tindakan antisipatif. Mengingat banyak didapati kenyataan bahwa para pengamen ini menghabiskan hasil ngamen untuk mabuk-mabukan, sedang para sales banyak melakukan penipuan terrhadap warga. Seperti diketahui motto Kota Gresik adalah Gresik berhias Iman, maka kondisi seperti tersebut di atas, jika tak diambil tindakan antisipatif akan melukai citra desa sekaligus bertentangan dengan motto Kabupaten sebagai pemerintah pusat. Disinilah apa yang namanya LINMAS (Perlindungan Masyarakat) digiatkan aktivitasnya di desa ini.

LINMAS dibentuk dengan penguatan kelembagaan yang diatur dalam PERDES (peraturan desa). Dengan demikian Sknya adalah SK dari Kepala Desa dan dalam melaksanakan tugasnya LINMAS bertanggungjawab kepada Kepala Desa. Para anggota LINMAS ini bertugas menjaga ketertiban desa, menanggulangi hal-hal yang tidak diinginkan seperti pencurian, perkelaian, perampasan, miras dan narkoba, pelecehan dan perjudian. Linmas bekerja dengan tiga shift, dimana kebutuhan pendanaan dan kesejahteraan anggotanya diupayakan oleh desa melalui hasil dari portal-portal yang ada. 


\section{KESIMPULAN}

Berdasarkan hasil penelitian dapat diambil kesimpulan, bahwa :

1) Konsep pembangunan kerjasama yang sinergis antara petani Lontar, pengusaha yang ada di desa, yang dalam hal ini adalah pengusaha warung-warung atau restoran yang ada dan pemerintah desa harus dilakukan. Kerjasama antara Warung Berkah Illahi dengan petani Lontar dapat menjadi contoh yang menarik. Petani Lontar terikat kontrak dengan pengusaha warung Berkah Illahi yang isinya adalah ikut bertanggung jawab secara moral atas hidangan minuman yang diberikan. Kepada para konsumen yang masih raguragu terhadap efek dari minuman legen yang dihidangkan, warung Berkah Illahi dapat menunjukkan legalisasi hidangan minuman yang diberikan oleh Bupati Gresik dan para tokoh masyarakat.

2) Model kerja sama kelembagaan akan melibatkan beberapa pihak diantaranya adalah asosiasi petani Lontar sebagai pemasok legen, asosiasi pengusaha warung, asosiasi pemasok ayam dan ikan, perangkat desa bidang usaha, perangkat desa bidang kerokhanian dan LINMAS serta Dinas Pertanian sebagai pembina.

\section{REKOMENDASI}

Rekomendasi yang diusulkan sebagai hasil dari penelitian antara lain :

1. Membina hubungan baik dengan industri sekitar

2. Meningkatkan kerjasama dengan pemerintah tingkat kecamatan dan Kabupaten, agar pembangunan di desa ini mendapat perhatian, mengingat potensi yang sangat menarik untuk dikembangkan menjadi desa wisata.

3. Meningkatkan keamanan dan pengamanan melalui perangkat yang ada.

4. Terus menerus mengadakan sosialisi re-positioning citra desa.

5. Konsumen yang mungkin akan menjadi konsumen setia adalah konsumen yang menyampaikan keluhan kepada kita.

6. Strategi bertahan melibatkan usaha yang dilakukan untuk mengurangi konsumen yang keluar dan beralih ke produk lain.

\section{DAFTAR KEPUSTAKAAN}

Christian Gronroos (2004), From Marketing Mix to Relationship Marketing, Management Decision, Vol 32 No. 2, Australia.

Cravens, 1997, Strategic Marketing, Richard D Irwin, a times mirror higher education group., inc. company, USA.

Istijanto, 2005, Aplikasi Praktis Riset Pemasaran, Gramedia Pustaka Utama, Jakarta.

Kartajaya, 2005, Marketing Plus 2000, Gramedia Pustaka Utama, Jakarta.

Kotler \& Keller, 2008, Manajemen Pemasaran, Terjemahan, ed. 13, Erlangga, Surabaya.

Kotler, P and G Armstrong, 1994, Principles of Marketing, 6th ed., Englewood Cliffs, N J, Prentice Hall International.inc.

Parasuraman, et.al (1998), SERVQUAL : A Multiple-Item Scale for Measuring Consumer Perception of Service Quality, Journal of Retailing, Spring, New York. 
Peterson, RA and WR Wilson, 1992, Measuring customer satisfaction, Journal Marketing. Spring, New York.

Ries Al and Jack Trout, Positioning, 2001, Terjemahan, Salemba Empat, Jakarta.
Tjiptono, F., 1994, Manajemen Jasa, Andi Offset, Yogjakarta.

Trout and Rivkin, 2004, Power of simplicity, terjemahan, Bhuana Ilmu Populer, Jakarta. 